\title{
Functional syndromes and symptom-orientated aftercare after esophagectomy
}

\author{
Kristjan Ukegjini $^{1,2} \cdot$ Diana Vetter $^{1} \cdot$ Rebecca Fehr $^{3} \cdot$ Valerian Dirr $^{1} \cdot$ Christoph Gubler $^{4} \cdot$ Christian A. Gutschow $^{1}$ (D)
}

Received: 25 April 2021 / Accepted: 16 May 2021 / Published online: 25 May 2021

(C) The Author(s) 2021

\begin{abstract}
Background Surgery is the cornerstone of esophageal cancer treatment but remains burdened with significant postoperative changes of gastrointestinal function and quality of life.

Purpose The aim of this narrative review is to assess and summarize the current knowledge on postoperative functional syndromes and quality of life after esophagectomy for cancer, and to provide orientation for the reader in the challenging field of functional aftercare.

Conclusions Post-esophagectomy syndromes include various conditions such as dysphagia, reflux, delayed gastric emptying, dumping syndrome, weight loss, and chronic diarrhea. Clinical pictures and individual expressions are highly variable and may be extremely distressing for those affected. Therefore, in addition to a mostly well-coordinated oncological follow-up, we strongly emphasize the need for regular monitoring of physical well-being and gastrointestinal function. The prerequisite for an effective functional aftercare covering the whole spectrum of postoperative syndromes is a comprehensive knowledge of the pathophysiological background. As functional conditions often require a complex diagnostic workup and long-term therapy, close interdisciplinary cooperation with radiologists, gastroenterologists, oncologists, and specialized nutritional counseling is imperative for successful management.
\end{abstract}

Keywords Esophagectomy $\cdot$ Functional syndromes $\cdot$ Functional aftercare $\cdot$ Quality of life $\cdot$ Dumping syndrome $\cdot$ Dysphagia Delayed gastric emptying

\section{Introduction}

Esophageal cancer is the eighth most common malignant tumor worldwide, accounting for approximately $3 \%$ of newly diagnosed carcinomas [1-3]. In Western countries, the incidence of adenocarcinoma has significantly increased over the past decades, although the reasons for this shift are not fully understood $[4,5]$.

Christian A. Gutschow

christian.gutschow@usz.ch

1 Department of Visceral and Transplant Surgery, University Hospital Zurich, Zurich, Switzerland

2 Department of General, Visceral, Endocrine and Transplant Surgery, Kantonsspital St. Gallen, St. Gallen, Switzerland

3 Department of Endocrinology, Diabetology and Clinical Nutrition, University Hospital Zurich, Zurich, Switzerland

4 Department of Gastroenterology and Hepatology, University Hospital Zurich, Zurich, Switzerland
It is commonly accepted that surgical resection represents the critical component of oncologic therapy. In this context, the extent of surgery critically depends on both location and growth pattern of the tumor. Distal esophagectomy in terms of an extended gastrectomy is usually performed for Siewert IIIII carcinoma of the esophago-gastric junction, whereas tumors located more proximally require subtotal or total esophagectomy with intrathoracic or cervical anastomosis. In most centers, standard reconstruction after esophagectomy is performed with a tubulized stomach, whereas a jejunal conduit as an esophageal substitute is an accepted alternative after distal esophagectomy. In contrast, reconstruction of the intestinal continuity with interposition of a colon segment is reserved for exceptional situations [6].

Perioperative morbidity and oncologic outcomes have long been the key measures of success in oncologic esophageal surgery. With the introduction of multimodal therapeutic strategies, long-term survival has significantly improved, and postoperative function and quality of life have increasingly come into focus in recent years [7]. Undisputedly, 
esophagectomy is a major and life-altering procedure, and less than $20 \%$ of patients report unimpaired postoperative alimentary comfort [8]. The most common functional conditions include dysphagia and reflux, dumping syndrome (DS), delayed gastric emptying (DGE), diarrhea, and weight loss. In view of a growing demand for competent functional aftercare, this review aims at providing a comprehensive summary of functional conditions after esophagectomy including an update on diagnosis and therapy.

\section{Dysphagia}

\section{Pathophysiology and symptoms}

Dysphagia is a common complaint after esophagectomy; however, only 3 to $4 \%$ of patients report clinically relevant symptoms $[8,9]$. Stenoses or strictures of the anastomotic area are the typical underlying causes, but functional conditionsparticularly after high cervical anastomosis - may also play an important role.

The pathogenesis of postoperative anastomotic stricture is not fully understood and probably multifactorial in terms of combined local ischemia and excessive anastomotic strain, promoting local inflammation, fibrin and collagen deposition, and consecutive scar formation $[10,11]$. Therefore, dysphagia is considerably more common after anastomotic leakage [12-14].

On the other hand, new-onset dysphagia after longer follow-up is often caused by peptic strictures resulting from caustic reflux and insufficient acid suppression (Fig. 1), which in turn may be catalyzed by chronic DGE. Dysphagia occurs more frequently after cervical anastomosis than after intrathoracic reconstruction, although underlying issues are multiple and often functional. In this context, the anastomotic technique may have an impact on the incidence of dysphagia, as there is evidence of lower stricture rates after mechanical sideto-side anastomosis compared with circular stapler or manual suture anastomosis [15-17]. Likewise, a correlation between smaller circular stapler diameter $(25 \mathrm{~cm})$ and higher stricture rate has been evidenced in a systematic review [18]. Recurrent nerve palsy is also more common after cervical esophagogastrostomy and confers an increased risk of aspiration [19].

Clinically, dysphagia may appear in varying degrees for all food consistencies, or exclusively for solids or liquids; the frequency of dysphagia also plays an important role. Therefore, detailed monitoring of symptoms is crucial. In this context, the Eckardt score - originally developed for the assessment of achalasia and its sequelae - allows for a straightforward and quick clinical evaluation (Table 1) [20].

\section{Diagnostic workup and therapy}

A targeted diagnostic workup for dysphagia after esophageal resection should start with endoscopy and contrast imaging. After exclusion of a mechanical cause or local recurrence, functional investigation of the laryngeal region including the upper esophageal sphincter with fiberoptic endoscopic evaluation (FEES) may provide further information.

Owing to their high restenosis rate, treatment of anastomotic strictures is a delicate undertaking. Endoscopic balloon dilatation or bougienage is currently considered the standard of care for benign anastomotic strictures [21, 22]. To avoid complications, strictures should be dilated by a maximum of three millimeter steps beginning from lowest resistance each time a dilation is performed [23]. Consequently, repeat endoscopies are often required for satisfactory results. Once an anastomotic width of more than $16 \mathrm{~mm}$ is achieved, patients can usually tolerate a normal diet [24]. In this context, simultaneous injection of corticosteroids may reduce complication rates and the number of dilatations required $[25,26]$. In support, adequate acid suppression with proton pump inhibitors is strongly recommended. In the case of secondary caustic reflux as the cause of stenosis, the underlying DGE must be treated according to the measures discussed below in the section "Delayed gastric emptying." Supportive dietary counseling including regular assessment of the nutritional status is crucial to prevent progressive weight loss. If oral caloric intake remains insufficient even after appropriate substitution with high-calorie sip feeds, insertion of a small-bowel feeding tube should be considered.
Fig. 1 Anastomotic stricture after esophagectomy with gastric conduit reconstruction and intrathoracic anastomosis. a) Impacted food bolus b) Anastomotic stricture
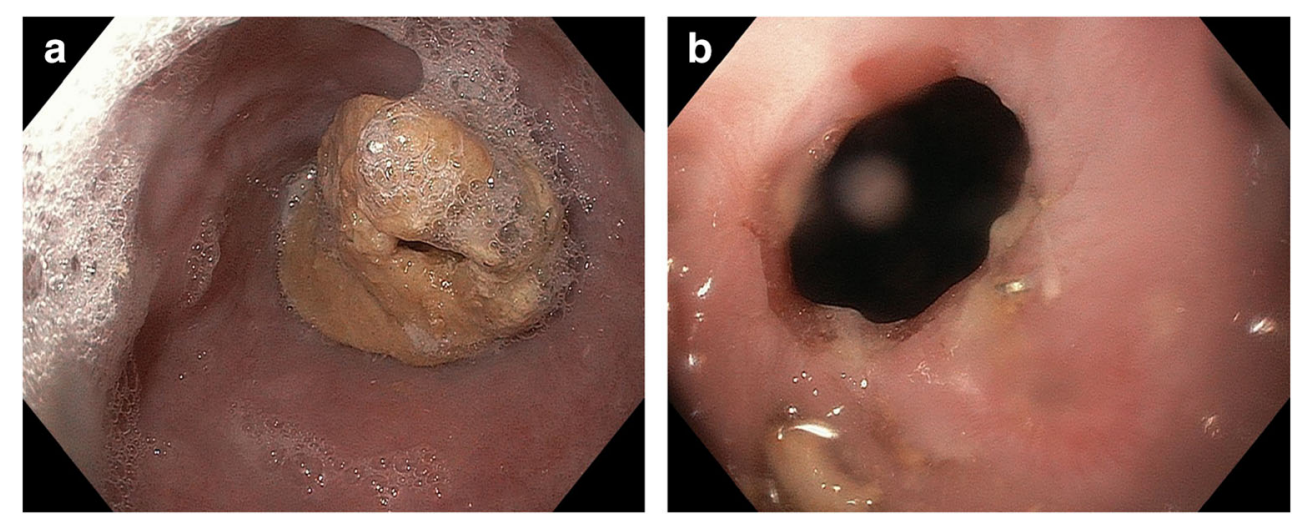
Table 1 Eckardt score for clinical assessment of dysphagia (20)

\begin{tabular}{lllll}
\hline Score & Symptoms & & \\
\cline { 2 - 5 } & Weight loss & Dysphagia & Chest pain & Regurgitation \\
\hline 0 & None & None & None & None \\
1 & $>5 \mathrm{~kg}$ & Occasionally/weekly & Occasionally/weekly & Occasionally/weekly \\
2 & $5-10 \mathrm{~kg}$ & Daily & Daily & Daily \\
3 & $>10 \mathrm{~kg}$ & Every meal & Every meal & Every meal \\
\hline
\end{tabular}

\section{Gastroesophageal reflux}

\section{Pathophysiology and symptoms}

Reflux symptoms after esophagectomy with gastric conduit reconstruction are reported by up to $60-80 \%$ of patients [27]. Often, symptoms manifest atypically in terms of coughing attacks, particularly when lying down or after meals. Several pathogenetic factors are discussed, including the loss of the natural antireflux barrier at the esophago-gastric junction and changed pressure conditions after transposition of the stomach into the negative thoracic pressure environment $[27,28]$. In addition, the impaired motility and emptying ability of the gastric conduit in combination with a regenerating acid secretion over time may play an important pathophysiological role [29, 30]. Furthermore, after both intrathoracic [31] and cervical [32] reconstruction, the level of anastomosis appears to impact on both frequency and severity of reflux symptoms. In this context, low intrathoracic anastomosis should generally be avoided due to the higher risk of reflux problems [12]. As a consequence of chronic reflux, severe esophagitis and meta- and dysplasia in terms of a neo-Barrett's esophagus may occur [33], and even de novo adenocarcinoma in the residual esophagus has been reported [34]. Nevertheless, the pathophysiological role of acidic and bilious reflux components has not been conclusively clarified [35].

\section{Diagnostic workup and therapy}

Endoscopy remains the most important diagnostic modality, allowing for both macroscopic assessment and histologic clarification. Endoscopy also provides clues regarding underlying DGE, such as repeated detection of food residues in the gastric lumen after adequate fasting and a spastic pylorus. From our point of view, further diagnostic evaluation by means of esophageal and/ or gastric long-term $\mathrm{pH}$-metry or impedance monitoring is not routinely indicated owing to the lack of therapeutic consequences. However, a standardized assessment of symptoms is recommended; in this regard, the GERD-HRQL score according to Velanovich [36] (Table 2) and the health-related quality of life (HRQL) questionnaires published by the European Organization for Research and Treatment of Cancer (EORTC) [37, 38] have proven their clinical benefit.

As a general recommendation after esophagectomy with gastric conduit reconstruction, the central therapeutic tool remains adequate long-term suppression of acid secretion with
Table 2 GERD-Health Related Quality of Life Questionnaire by Velanovich [36]

\begin{tabular}{|c|c|c|c|c|c|c|}
\hline \multirow[b]{2}{*}{ How bad is the heartburn? } & \multicolumn{6}{|c|}{ Scale } \\
\hline & 0 & 1 & 2 & 3 & 4 & 5 \\
\hline Heartburn when lying down? & 0 & 1 & 2 & 3 & 4 & 5 \\
\hline Heartburn when standing up? & 0 & 1 & 2 & 3 & 4 & 5 \\
\hline Heartburn after meals? & 0 & 1 & 2 & 3 & 4 & 5 \\
\hline Does heartburn change your diet? & 0 & 1 & 2 & 3 & 4 & 5 \\
\hline Does heartburn wake you from sleep? & 0 & 1 & 2 & 3 & 4 & 5 \\
\hline Do you have difficulty swallowing? & 0 & 1 & 2 & 3 & 4 & 5 \\
\hline Do you have gassy or bloating feeling? & 0 & 1 & 2 & 3 & 4 & 5 \\
\hline Do you have pain while swallowing? & 0 & 1 & 2 & 3 & 4 & 5 \\
\hline If you take reflux medication, does this affect your daily life? & 0 & 1 & 2 & 3 & 4 & 5 \\
\hline How satisfied are you with your current health condition? & \multicolumn{2}{|c|}{ Satisfied } & \multicolumn{2}{|c|}{ Neutral } & \multicolumn{2}{|c|}{ Dissatisfied } \\
\hline
\end{tabular}

Scale 0: no symptoms; scale 1: noticeable, but not bothersome; scale 2: noticeable, bothersome, but not every day; scale 3: bothersome daily; scale 4: bothersome and affects daily activities; scale 5 : incapacitating to do daily activities 
high-dose proton pump inhibitors (PPI). In severe or refractory symptoms, administration of $\mathrm{H} 2$-blockers or alginates may provide additional symptom relief. In suspected DGE as underlying cause of reflux symptoms, the specific endoscopicinterventional and conservative-prokinetic measures as described below should be followed.

\section{Delayed gastric emptying}

\section{Pathophysiology and symptoms}

Fifteen to $30 \%$ of patients after esophagectomy with gastric conduit reconstruction report typical symptoms of DGE [39]. The underlying mechanism is not fully understood, the most important pathophysiologic causes being impaired antropyloro-duodenal motility due to vagal and sympathetic denervation and transposition of the stomach to the thoracic negative-pressure compartment [40, 41]. In individual cases however, other factors such as diameter, volume, and redundancy of the gastric conduit, a prominent right diaphragmatic crus causing a kinked course of the conduit, the route chosen for reconstruction (posterior or anterior mediastinum), or a transhiatal prolapse of abdominal organs in terms of an enterothorax may be causative of DGE [42-44].

It remains controversial whether prophylactic intraoperative pyloric drainage via pyloroplasty or pyloromyotomy can lead to a significant reduction in the incidence of DGE. Moreover, with the introduction of minimally invasive surgical techniques, these procedures are used less frequently [45]. Reduced incidence of DGE after pyloric drainage has been evidenced in a meta-analysis [46], however without significant effect on the rate of other postoperative complications. In contrast, a more recent analysis of the literature [47] failed to prove significant effects of pyloric drainage, although the authors caveat that the lack of definition of DGE in the included studies significantly limits their power. Perioperative injection of botulinum toxin into the pylorus is a relatively new technique [48, 49]; however, further research is needed to prove its clinical value. The same applies to diversion of the tubular stomach by means of a Rouxen-Y or Billroth II jejunal loop [50].

The symptomatology of DGE ranges from early satiety, thoracic pain, and reflux symptoms to regurgitation and vomiting. However, the complex interplay of many potentially causative factors significantly complicates the clinical assessment and limits the evaluability of the current literature regarding incidence and the effectiveness of therapeutic interventions $[42,47]$. In this context, the diagnostic criteria and the new grading system for DGE, published as part of an international consensus of experts, represent an important step forward (Table 3) [51].

\section{Diagnostic workup and therapy}

The first diagnostic step should focus on mechanical causes of DGE such as tumor recurrence or redundancy, kinking, or torsion of the conduit. Endoscopy and radiological investigations in terms of computed tomography and conventional contrast imaging are indicative in this regard. However, conventional chest X-ray often already reveals a characteristic pattern with a dilated conduit and air-fluid level (Fig. 2). During endoscopy, food residua in the gastric lumen after adequate fasting may be indicative for DGE (Fig. 3). In clinically unclear situations, a diagnostic attempt to detect gastroparesis can be made with gastric emptying scintigraphy [52] or a "smart pill" (Given Imaging, Yoqneam, Israel), which uses wireless transmission of $\mathrm{pH}$ data to indicate passage across the pylorus into the alkaline duodenal environment. Similarly, the ${ }^{13} \mathrm{C}$-octanoate breath test monitors the transpyloric passage of a ${ }^{13} \mathrm{C}$-isotope labeled meal. A new technique for planimetric assessment of pyloric distensibility has recently become available in the form of the Functional Luminal Imaging Probe (FLIP) [53, 54], although the clinical value of the test has not yet been conclusively established.

DGE can lead to relevant malnutrition, which is why competent nutritional counseling is generally recommended. As a rule, frequent small meals, a low-fat and low-fiber diet, and liquid or pureed foods are generally preferred since gastric emptying is often preserved for softer consistencies. In

Table 3 Scoring system for delayed gastric emptying by Konradsson et al. [45]

\begin{tabular}{|c|c|c|c|c|}
\hline \multirow{2}{*}{$\begin{array}{l}\text { Questions: } \\
\text { Have you felt full up too quickly while having your meal during the past week? }\end{array}$} & \multicolumn{4}{|c|}{ Score } \\
\hline & 0 & 1 & 2 & \\
\hline Have you vomited during the past week? & 0 & 1 & 2 & \\
\hline Have you felt nausea during the past week? & 0 & 1 & 2 & \\
\hline Have you had acid, bile or food coming up into your throat or mouth during the past week. & 0 & 1 & 2 & \\
\hline Have you been unable to eat or drink enough to meet your daily need for energy during the past week? & 0 & 1 & 2 & \\
\hline
\end{tabular}

Scale 0 : not at all; scale 1: a little; scale 2: quite a bit; scale 3: very much 


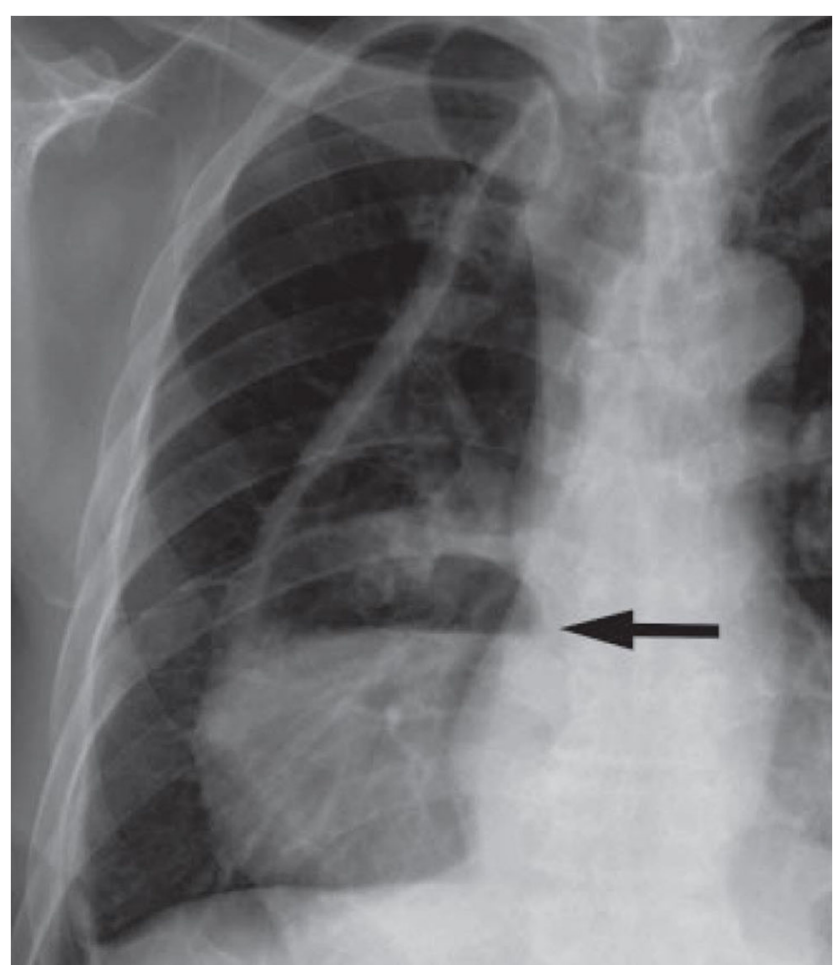

Fig. 2 Plain chest X-ray showing a dilated gastric conduit with air-fluid level in a patient with DGE after esophagectomy and gastric conduit reconstruction

addition, a number of prokinetic medications are available for treatment of DGE: Metoclopramide is a widely used drug with propulsive and antiemetic properties. The propulsive activity is mediated by an antagonizing effect on the dopamine receptors of the enteric nervous system and increased release of acetylcholine from cholinergic neurons and sensitization of muscarinic receptors [55]. However, approval has been restricted in 2014 by the German Federal Institute for Drugs and Medical Devices because of potentially irreversible

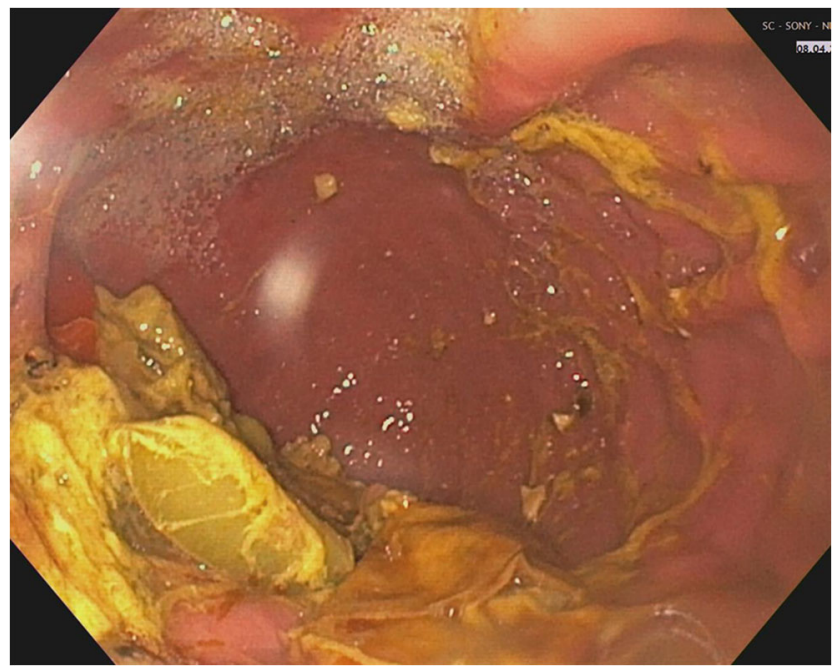

Fig. 3 Endoscopic aspect of food residua in the gastric conduit in a patient with DGE extrapyramidal parkinsonoid dyskinesia, which occurs in up to $10 \%$ of long-term users [56]. Domperidone has a similar mechanism of action, but less neurological side effects. However, dosage should not exceed $60 \mathrm{mg}$ daily in elderly patients because of possible QT-time prolongation [57]. Erythromycin and azithromycin are macrolide antibiotics that are also used as prokinetic drugs due to their agonistic effect on motilin receptors, which are ubiquitously present in the GI tract. Erythromycin is considered a potent agent for accelerating gastric emptying and is therefore indicated in postoperative gastroparesis [58]. After esophagectomy and gastric conduit reconstruction, the combination of pyloric drainage with administration of erythromycin leads to a relevant reduction in bilious duodeno-gastric reflux [59]. Prucalopride is a relatively new drug, originally conceived for chronic constipation. It is a serotonin receptor agonist and chemically related to cisapride, but without its arrhythmogenic properties [57]. Prucalopride leads to an acceleration of gastric emptying as part of a general increase in gastrointestinal motility and can be used to treat DGE.

Interventional procedures to improve gastric emptying include dilation of the pylorus using balloons (Fig. 4) [60-63]; using the novel FLIP technique, dilation can also be performed in a controlled manner [64]. In contrast, perioperative injection of botulinum toxin into the pylorus aiming at improving postoperative drainage is not generally recommended. Other procedures for the treatment of DGE after esophagectomy include peroral endoscopic myotomy of the pyloric region (G-POEM) $[65,66]$ or the implantation of neurostimulators [67, 68]; however, the published evidence is too limited to make general recommendations [45]. In our own approach, diversion of the conduit with a jejunal loop according to Roux-en-Y has proven effective in individual situations [50].

\section{Dumping syndrome}

\section{Pathophysiology and symptoms}

DS is observed in up to $50 \%$ of patients after esophagectomy, with only $1-5 \%$ of patients showing pronounced symptoms [28]. The cause of DS is a lack of storage and accommodation capacity of the tubulized stomach plus vagotomy-related impaired antro-pyloro-duodenal motility. The above factors lead to unfractionated flooding of the small intestine with food and consecutive systemic reactions. In addition to the changes in anatomy and vagal innervation, disturbed neural and endocrine feedback via the osmotic and mechanical sensors in the small intestine also plays an important role. Thus, the interplay of a variety of gastrointestinal peptide hormones involved in digestion, such as GLP-1, CCK, PYY, PP, VIP, and neurotensin, is profoundly transformed after esophagectomy [69]. 
Fig. 4 Fluoroscopy-guided endoscopic dilation of pyloric spasm causing DGE. The black arrow marks the pyloric region. a Before dilation, b balloon

dilation, $\mathbf{c}$ endoscopic aspect after dilation

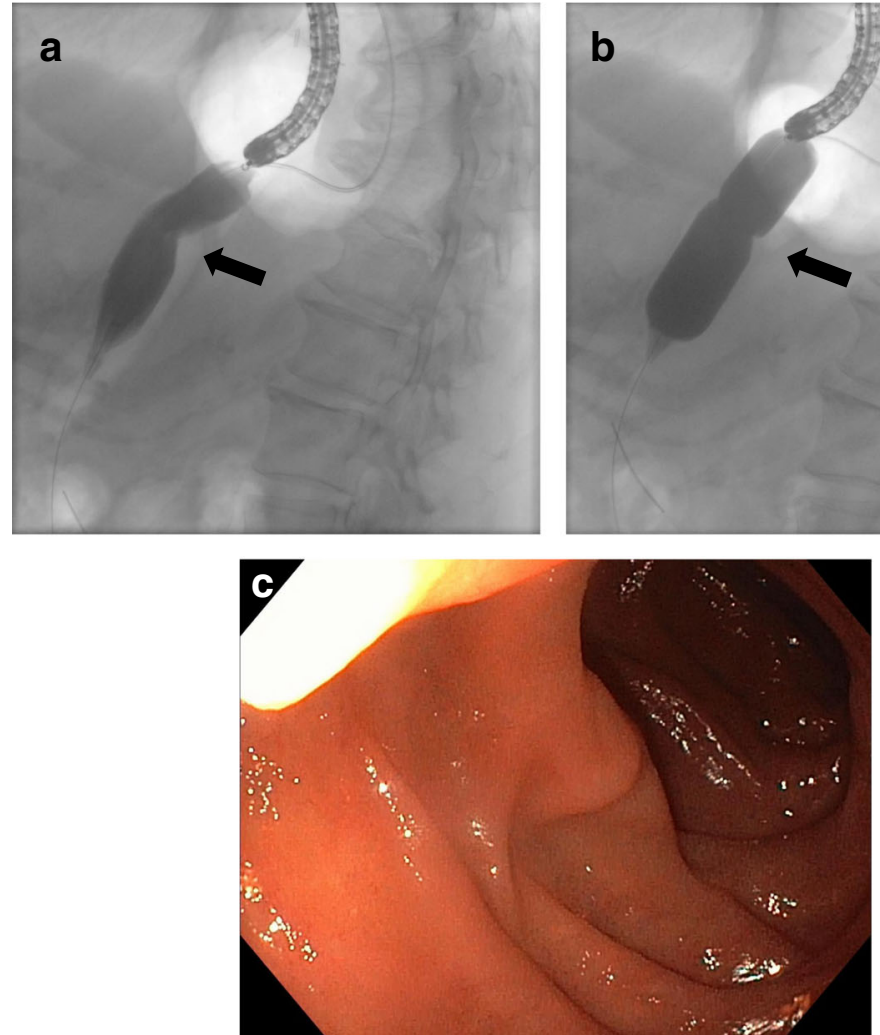

Diagnostic workup and therapy

DS can clinically be distinguished into early and late dumping according to the timing of postprandial onset. Reported incidences of early and late DS vary from 40 to $70 \%$ and 20 to $40 \%$, respectively, with frequent overlap between both syndromes [70].

Early DS (Table 4) is characterized by gastrointestinal and vasomotor symptoms, including bloating, abdominal pain, cramping, flatulence, diarrhea, circulatory problems, and even syncope. Symptoms usually start 10 to $30 \mathrm{~min}$ postprandially. Accelerated influx of hyperosmolar chyme to the small intestine results in a shift of fluid from the interstitial space to the intestinal lumen with consecutive increase of blood circulation in the splanchnic area, hypovolemia, hypotension, and a tendency to collapse. Mechanical stretching of the intestinal wall also results in vasomotor activation with compensatory activation of the renin-angiotensin system and hypersecretion of intestinal peptide hormones [71, 72].

In contrast, late DS typically occurs 1 to $3 \mathrm{~h}$ after meals with mixed symptoms of sweating, tremor, hunger, irritability, and lightheadedness. Due to the lack of pre-digestion, relatively large amounts of rapidly absorbable carbohydrates enter the small intestine, initially leading to hyperglycemia and followed by excessive insulin secretion with consecutive hypoglycemia [73-75]. Excessive release of GLP-1 may also play a role in reactive hypoglycemia; nevertheless, it remains ultimately unclear why only a proportion of patients becomes symptomatic [76].
DS is a clinical diagnosis made from the typical constellation of symptoms after gastric or esophageal surgery. Monitoring of the effectiveness of therapeutic measures can be performed with the Sigstad symptom score [77] (Table 5). In severe DS, it is recommended to perform an oral glucose tolerance test, in which symptoms, pulse rate, blood pressure, hematocrit, and serum glucose are monitored at 30-min intervals before and after glucose ingestion. Early or late DS can thus be detected with high sensitivity and specificity [78]. In contrast, scintigraphic gastric emptying or breath tests were not considered helpful in a recent expert consensus [79].

Table 4 Signs and symptoms of early and late dumping syndrome

\begin{tabular}{lll}
\hline \multicolumn{2}{l}{ Early dumping symptoms } & Late dumping symptoms \\
\cline { 1 - 1 } Gastrointestinal & Vasovagal & \\
\hline Feeling bloated & Flushing & Sweating \\
Abdominal cramps & Headache & Flushing \\
Diarrhea & Loss of consciousness & Dizziness, lightheadedness \\
Nausea & Weakness & Rapid heart rate \\
Vomiting & Palpitations & Weakness \\
Borborygmi & Paleness & Tremor \\
\hline & &
\end{tabular}


Table 5 Symptom score for dumping syndrome by Sigstad [77]

\begin{tabular}{lc}
\hline Symptoms & Sigstad score \\
\hline Shock & +5 \\
Fainting, syncope, unconsciousness & +4 \\
Desire to lie or sit down & +4 \\
Breathlessness, dyspnea & +3 \\
Weakness, exhaustion & +3 \\
Sleepiness, drowsiness, apathy, falling asleep & +3 \\
Palpitation & +3 \\
Restlessness & +2 \\
Dizziness & +2 \\
Headaches & +1 \\
Feeling of warmth, sweating, pallor, clammy skin & +1 \\
Nausea & +1 \\
Abdominal fullness, meteorism & +1 \\
Borborygmus & +1 \\
Eructation & -1 \\
Vomiting & -4 \\
Total Sigstad Score & \\
\hline
\end{tabular}

Score $>7$ : suspicion of dumping syndrome; score 4-7: no reliable assessment possible; score <7: no suspected dumping syndrome
The first therapeutic step should include nutritional counseling aiming at reduced carbohydrate intake and frequent small meals. In addition, liquids should be avoided during meals, as this accelerates food passage and increases the feeling of satiety. Complementary pharmacological approaches range from increasing chyme viscosity with guaran to the prescription of acarbose or diazoxide. Acarbose reduces rapid absorption of glucose by prevention of enzymatic cleaving of polysaccharides into smaller molecules. Diazoxide inhibits the secretion of insulin and is particularly indicated in late DS. Somatostatin or corresponding analogues may also be considered; however, the need for parenteral application is a major problem [28]. In this context, long-lasting somatostatin analogues with once monthly application have also shown to be effective [80].

\section{Nonspecific postoperative syndromes}

Some of the most common symptoms and dysfunctions after esophagectomy cannot be clearly assigned and probably correspond to an overlap or a partial manifestation of the "classic" categories described above. In our experience, the most relevant nonspecific postoperative complaints are excessive weight loss with malnutrition on the one hand and persistent diarrhea or steatorrhoea on the other.

Even after an uncomplicated postoperative course and diet build-up, almost all patients experience unwanted weight loss after esophagectomy. The extent is typically related to the general nutritional status and is particularly pronounced in patients with severe preoperative weight loss, sarcopenia, advanced age, and vocal cord paralysis [81]. Consequently, early nutritional counseling is mandatory for preventing malnutrition during the initial postoperative phase. In our own practice, $5 \%$ weight loss over the first three postoperative months is tolerated without further intervention. Nevertheless, we strongly recommend careful screening of the nutritional status according to the ESPEN criteria (European Society for Clinical Nutrition and Metabolism) to monitor protein and caloric intake and to determine the need for nutritional supplements $[82,83]$. In patients with a weight loss $>5 \%$ or a BMI $<18.5 \mathrm{~kg} / \mathrm{m}^{2}$, close clinical monitoring and supplementation with high-caloric nutrition is indicated. If oral nutritional intake remains insufficient, we usually recommend insertion of a small-bowel feeding tube. Additional parenteral nutrition should only be performed in exceptional cases because of higher complication rates [84].

Chronic diarrhea and steatorrhea are frequent complaints after esophagectomy. Often, symptoms overlap with DS and require a similar diagnostic and therapeutic approach. Nevertheless, exclusion of infectious colitis or even a clostridial colonization by stool culture is generally indicated in this situation. In case of persistent chronic diarrhea limiting quality of life, symptomatic treatment with peristaltic inhibitors such as loperamide hydrochloride and probiotics should be considered. Similar to gastric resection, exocrine pancreatic insufficiency $[85,86]$ may lead to maldigestion and malabsorption with consecutive steatorrhea, meteorism, and intolerance of 
various foods. Determination of elastase- 1 and stool fat content can provide additional information, and oral substitution of pancreatic enzymes is recommended.

\section{Health-related quality of life after esophagectomy}

As with any malignant disease, the diagnosis of esophageal cancer has a significant impact on the overall and organspecific health-related quality of life (HRQL). Curative therapy aims at curing the patient and restoring quality of life as completely as possible. However, due to the oncologic aggressiveness of the disease and the complexity of the surgical procedure - with significant changes to the upper gastrointestinal tract physiology - this goal is not always achievable [30, 87].

HRQL is defined as the extent to which physical, emotional, and social well-being is affected by a disease or its therapy [36]. Measurement of HRQL after surgical interventions has become increasingly important in recent years. Selfassessment scales, such as the EORTC quality of life questionnaires [88] and the Eypasch gastrointestinal quality of life index (GILQI) [89], are among the most frequently used.

There is general consensus that early postoperative quality of life is reduced after esophagectomy compared with preoperative levels [70] and healthy reference populations [90-94]. However, most authors agree that in the majority of patients, significant functional recovery takes place over the first 1-2 years $[70,95]$. This dynamic can be explained both by a resolution of the immediate side effects of surgery during early recovery and by an increasing tolerance towards residual symptoms during long-term follow-up [38].

Nevertheless, the overall published evidence on mid- and long-term quality of life after esophagectomy is controversial, ranging from largely complete recovery without detectable deficits [9, 96-99] to permanent impairment [100-102]. However, the majority of studies show that most dimensions of HRQL remain reduced in the long term compared with healthy reference populations [94, 103-105], an effect apparently independent of surgical access routes or additional radiochemotherapy or chemotherapy $[37,38,94,102,103,106$, 107]. Similarly, there is no evidence for a significant influence of gender, tumor histology, or tumor stage on postoperative HRQL [37]. In contrast, postoperative complications such as anastomotic leakage may well have a sustained negative impact [94]. Nevertheless, most studies show that acceptable HRQL in the long-term follow-up after esophagectomy is possible in a high percentage of individuals $[89,90]$. For example, in our own retrospective study, HRQL scores of $50 \%$ of patients $>12$ months after Ivor Lewis esophagectomy were at the same level compared with a healthy reference population. [38]

\section{Summary}

Resection and replacement of the esophagus remain the critical components of curative therapy for esophageal cancer. Along with the progressive centralization of esophageal

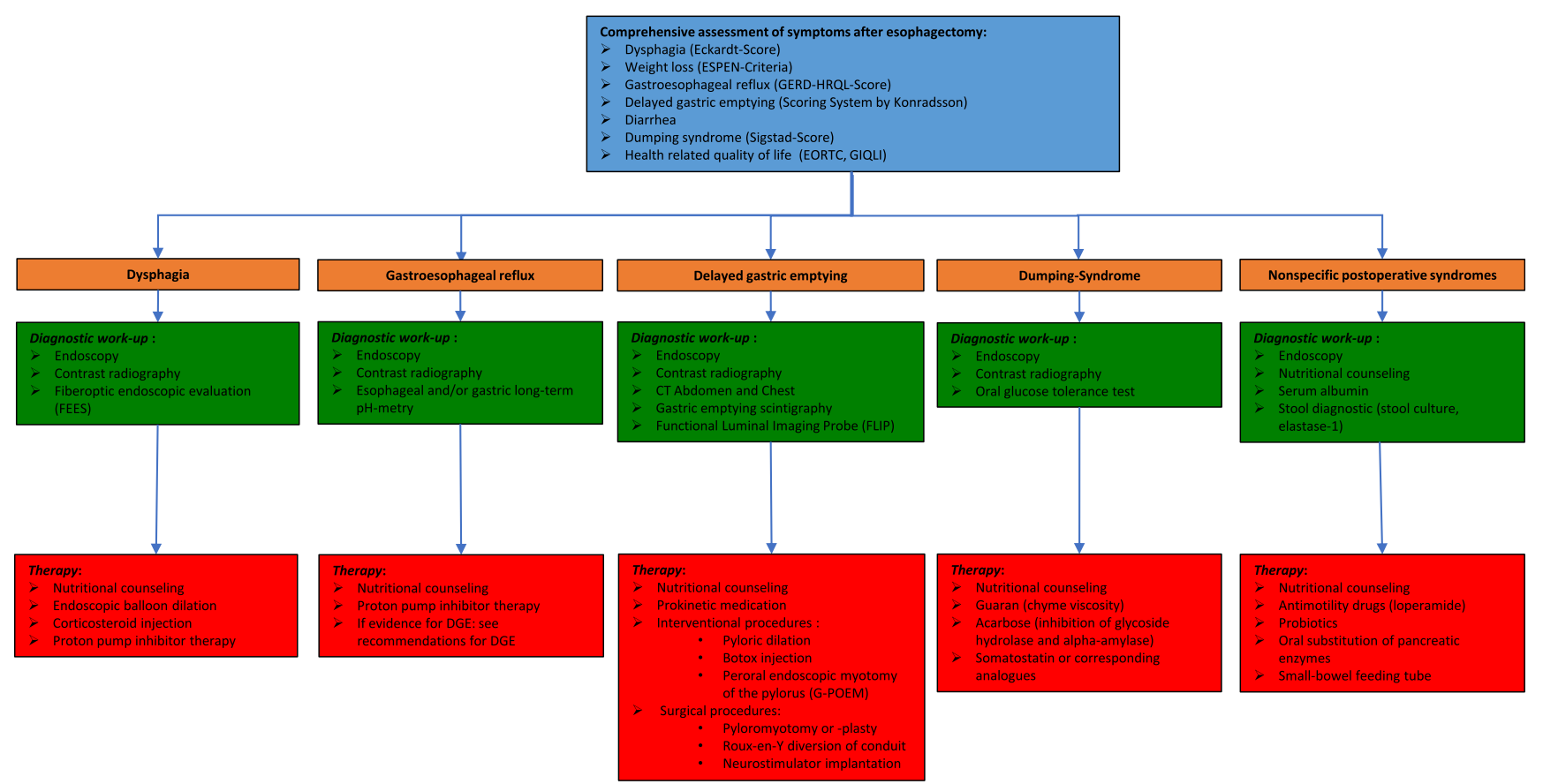

Fig. 5 Diagnostic and therapeutic algorithm for functional syndromes after esophagectomy 
surgery in recent years, there has been a shift to highly specialized treatment in many Western countries. The increase in surgical expertise that came with this dynamic and the growing popularity of minimally invasive procedures has led to a reduction in perioperative morbidity and mortality $[108]$ and probably also to an improvement in oncologic radicality [109]. However, despite the undeniable benefits of modern surgery, esophagectomy implies a considerable mutilation of the individual physiology, as the basic principles of surgical technique, which were established decades ago, remain largely unchanged [110]. Functional conditions after esophagectomy are highly diverse regarding clinical picture and individual expression and may be extremely distressing for those affected. Therefore, in addition to a mostly well-coordinated oncological follow-up, we strongly emphasize the need for regular monitoring of physical well-being and gastrointestinal function. The prerequisite for an effective "functional aftercare" that covers the whole spectrum of postoperative syndromes is the detailed and comprehensive knowledge of the pathophysiological background. As some functional conditions require a complex diagnostic workup and even long-term therapy, close interdisciplinary cooperation with radiologists, gastroenterologists, oncologists, and specialized nutritional counseling is imperative for a successful management (Fig. 5).

Availability of data and material (data transparency) Not applicable.

Code availability Not applicable.

Authors' contributions Christian Gutschow designed, drafted, and revised the manuscript. Kristjan Ukegjini and Diana Vetter drafted and revised the manuscript. Valerian Dirr, Rebecca Fehr, and Christoph Gubler critically revised the manuscript.

Funding Open Access funding provided by Universität Zürich.

\section{Declarations}

Ethics approval Not applicable.

Consent to participate Not applicable.

Consent for publication Not applicable.

Competing interests The authors declare no competing interests.

Open Access This article is licensed under a Creative Commons Attribution 4.0 International License, which permits use, sharing, adaptation, distribution and reproduction in any medium or format, as long as you give appropriate credit to the original author(s) and the source, provide a link to the Creative Commons licence, and indicate if changes were made. The images or other third party material in this article are included in the article's Creative Commons licence, unless indicated otherwise in a credit line to the material. If material is not included in the article's Creative Commons licence and your intended use is not permitted by statutory regulation or exceeds the permitted use, you will need to obtain permission directly from the copyright holder. To view a copy of this licence, visit http://creativecommons.org/licenses/by/4.0/.

\section{References}

1. statistics ACSC. Cancer fact sheets. https://wwwcancerorg/cancer/ all-cancer-typeshtml accessed January 9, 2021.

2. observatory IAfRoCGc. Cancer fact sheets. http://gcoiarcfr/today/ fact-sheets-cancers accessed January 9, 2021.

3. Mattiuzzi C, Lippi G (2019) Current cancer epidemiology. J Epidemiol Glob Health 9:217-222. https://doi.org/10.2991/jegh. k.191008.001

4. Arnold M, Laversanne M, Brown LM, Devesa SS, Bray F (2017) Predicting the future burden of esophageal cancer by histological subtype: international trends in incidence up to 2030. Am J Gastroenterol 112:1247-1255. https://doi.org/10.1038/ajg.2017. 155

5. Allemani C, Matsuda T, Di Carlo V et al (2018) Global surveillance of trends in cancer survival 2000-14 (CONCORD-3): analysis of individual records for 37513025 patients diagnosed with one of 18 cancers from 322 population-based registries in 71 countries. Lancet 391:1023-1075. https://doi.org/10.1016/ S0140-6736(17)33326-3

6. Holscher AH, Gockel I, Porschen R (2019) Updated German S3 guidelines on esophageal cancer and supplements from a surgical perspective. Chirurg 90:398-402. https://doi.org/10.1007/s00104019-0954-9

7. Langenhoff BS, Krabbe PF, Wobbes T et al (2001) Quality of life as an outcome measure in surgical oncology. Br J Surg 88:643652. https://doi.org/10.1046/j.1365-2168.2001.01755.x

8. Headrick JR, Nichols FC 3rd, Miller DL et al (2002) High-grade esophageal dysplasia: long-term survival and quality of life after esophagectomy. Ann Thorac Surg 73:1697-1702; discussion 1702-1693. https://doi.org/10.1016/s0003-4975(02)03496-3

9. McLarty AJ, Deschamps C, Trastek VF et al (1997) Esophageal resection for cancer of the esophagus: long-term function and quality of life. Ann Thorac Surg 63:1568-1572. https://doi.org/ 10.1016/s0003-4975(97)00125-2

10. Blackmon SH, Correa AM, Wynn B, Hofstetter WL, Martin LW, Mehran RJ, Rice DC, Swisher SG, Walsh GL, Roth JA, Vaporciyan AA (2007) Propensity-matched analysis of three techniques for intrathoracic esophagogastric anastomosis. Ann Thorac Surg 83:1805-1813; discussion 1813. https://doi.org/10.1016/j. athoracsur.2007.01.046

11. Rice TW (2006) Anastomotic stricture complicating esophagectomy. Thorac Surg Clin 16:63-73. https://doi.org/10.1016/j. thorsurg.2006.02.002

12. D'Journo XB, Martin J, Rakovich G et al (2009) Mucosal damage in the esophageal remnant after esophagectomy and gastric transposition. Ann Surg 249:262-268. https://doi.org/10.1097/SLA. 0b013e31818eec06

13. van Heijl M, Gooszen JA, Fockens P, Busch OR, Jan van Lanschot J, van Berge Henegouwen MI (2010) Risk factors for development of benign cervical strictures after esophagectomy. Ann Surg 251:1064-1069. https://doi.org/10.1097/SLA. 0b013e3181deb4b7

14. van der Schaaf M, Lagergren J, Lagergren P (2012) Persisting symptoms after intrathoracic anastomotic leak following oesophagectomy for cancer. Br J Surg 99:95-99. https://doi.org/ 10.1002/bjs. 7750

15. Deng XF, Liu QX, Zhou D, Min JX, Dai JG (2015) Hand-sewn vs linearly stapled esophagogastric anastomosis for esophageal cancer: a meta-analysis. World J Gastroenterol 21:4757-4764. https:// doi.org/10.3748/wjg.v21.i15.4757

16. Vetter D, Gutschow CA (2020) Strategies to prevent anastomotic leakage after esophagectomy and gastric conduit reconstruction. Langenbeck's Arch Surg 405:1069-1077. https://doi.org/10.1007/ s00423-020-01926-8 
17. Zhou D, Liu QX, Deng XF, Min JX, Dai JG (2015) Comparison of two different mechanical esophagogastric anastomosis in esophageal cancer patients: a meta-analysis. J Cardiothorac Surg 10:67. https://doi.org/10.1186/s13019-015-0271-4

18. Allen W, Wells CI, Greenslade M, Bissett IP, O’Grady G (2018) Association between circular stapler diameter and stricture rates following gastrointestinal anastomosis: systematic review and meta-analysis. World J Surg 42:3097-3105. https://doi.org/10.1007/ s00268-018-4606-x

19. Koh P, Turnbull G, Attia E et al (2004) Functional assessment of the cervical esophagus after gastric transposition and cervical esophagogastrostomy. Eur J Cardiothorac Surg 25:480-485. https://doi.org/10.1016/j.ejcts.2003.12.034

20. Eckardt VF, Aignherr C, Bernhard G (1992) Predictors of outcome in patients with achalasia treated by pneumatic dilation. Gastroenterology 103:1732-1738. https://doi.org/10.1016/00165085(92)91428-7

21. Huang Q, Zhong J, Yang T, Li J, Luo K, Zheng Y, Yang H, Fu J (2015) Impacts of anastomotic complications on the health-related quality of life after esophagectomy. J Surg Oncol 111:365-370. https://doi.org/10.1002/jso.23837

22. van Boeckel PG, Siersema PD (2015) Refractory esophageal strictures: what to do when dilation fails. Curr Treat Options Gastroenterol 13:47-58. https://doi.org/10.1007/s11938-0140043-6

23. Standards of Practice C, Egan JV, Baron TH et al (2006) Esophageal dilation. Gastrointest Endosc 63:755-760. https:// doi.org/10.1016/j.gie.2006.02.031

24. van Halsema EE, Noordzij IC, van Berge Henegouwen MI, Fockens P, Bergman JJ, van Hooft JE (2017) Endoscopic dilation of benign esophageal anastomotic strictures over $16 \mathrm{~mm}$ has a longer lasting effect. Surg Endosc 31:1871-1881. https://doi.org/ 10.1007/s00464-016-5187-0

25. Dasari CS, Jegadeesan R, Patel HK, Desai M, Aziz M, Thoguluvachandrasekar V, Duvvuri A, Kohli DR, Repici A, Siersema PD, Sharma P (2020) Intralesional steroids and endoscopic dilation for anastomotic strictures after esophagectomy: systematic review and meta-analysis. Endoscopy 52:721-726. https://doi.org/10.1055/a-1172-5975

26. Hanaoka N, Ishihara R, Motoori M, Takeuchi Y, Uedo N, Matsuura N, Hayashi Y, Yamada T, Yamashina T, Higashino K, Akasaka T, Yano M, Ito Y, Miyata H, Sugimura K, Hamada K, Yamasaki Y, Kanesaka T, Aoi K, Ito T, Iishi H (2018) Endoscopic balloon dilation followed by intralesional steroid injection for anastomotic strictures after esophagectomy: a randomized controlled trial. Am J Gastroenterol 113:1468-1474. https:// doi.org/10.1038/s41395-018-0253-y

27. Aly A, Jamieson GG (2004) Reflux after oesophagectomy. Br J Surg 91:137-141. https://doi.org/10.1002/bjs.4508

28. Donington JS (2006) Functional conduit disorders after esophagectomy. Thorac Surg Clin 16:53-62. https://doi.org/10.1016/j. thorsurg.2006.01.002

29. da Rocha JR, Ribeiro U Jr, Sallum RA et al (2008) Barrett's esophagus (BE) and carcinoma in the esophageal stump (ES) after esophagectomy with gastric pull-up in achalasia patients: a study based on 10 years follow-up. Ann Surg Oncol 15:2903-2909. https://doi.org/10.1245/s10434-008-0057-1

30. Gutschow C, Collard JM, Romagnoli R, Salizzoni M, Hölscher A (2001) Denervated stomach as an esophageal substitute recovers intraluminal acidity with time. Ann Surg 233:509-514. https://doi. org/10.1097/00000658-200104000-00005

31. Usui H, Fukaya M, Itatsu K, Miyata K, Miyahara R, Funasaka K, Nagino M (2018) The impact of the location of esophagogastrostomy on acid and duodenogastroesophageal reflux after transthoracic esophagectomy with gastric tube reconstruction and intrathoracic esophagogastrostomy. World J Surg 42:599-605. https://doi.org/10.1007/s00268-017-4186-1

32. Sakai M, Sohda M, Miyazaki T, Yoshida T, Kumakura Y, Honjo H, Hara K, Yokobori T, Kuwano H (2017) Impact of the level of anastomosis on reflux esophagitis following esophagectomy with gastric tube reconstruction. World J Surg 41:804-809. https://doi. org/10.1007/s00268-016-3786-5

33. Dunn LJ, Shenfine J, Griffin SM (2015) Columnar metaplasia in the esophageal remnant after esophagectomy: a systematic review. Dis Esophagus 28:32-41. https://doi.org/10.1111/dote.12129

34. Gutschow CA, Vallbohmer D, Stolte M et al (2008) Adenocarcinoma developing in de novo Barrett's mucosa in the remnant esophagus after esophagectomy: clinical and molecular assessment. Dis Esophagus 21:E6-E8. https://doi.org/10.1111/j. 1442-2050.2007.00784.x

35. O'Riordan JM, Tucker ON, Byrne PJ, McDonald G, Ravi N, Keeling PWN, Reynolds JV (2004) Factors influencing the development of Barrett's epithelium in the esophageal remnant postesophagectomy. Am J Gastroenterol 99:205-211. https://doi. org/10.1111/j.1572-0241.2004.04057.x

36. Velanovich V (2007) The development of the GERD-HRQL symptom severity instrument. Dis Esophagus 20:130-134. https://doi.org/10.1111/j.1442-2050.2007.00658.x

37. Fuchs H, Holscher AH, Leers J et al (2016) Long-term quality of life after surgery for adenocarcinoma of the esophagogastric junction: extended gastrectomy or transthoracic esophagectomy? Gastric Cancer 19:312-317. https://doi.org/10.1007/s10120-0150466-3

38. Gutschow CA, Holscher AH, Leers J et al (2013) Health-related quality of life after Ivor Lewis esophagectomy. Langenbeck's Arch Surg 398:231-237. https://doi.org/10.1007/s00423-0120960-6

39. Anderson MJ, Sippey M, Marks J (2020) Gastric per oral pyloromyotomy for post-vagotomy-induced gastroparesis following esophagectomy. J Gastrointest Surg 24:715-719. https://doi. org/10.1007/s11605-019-04418-3

40. Collard JM, Romagnoli R, Otte JB, Kestens PJ (1998) The denervated stomach as an esophageal substitute is a contractile organ. Ann Surg 227:33-39. https://doi.org/10.1097/00000658199801000-00005

41. Lee HS, Kim MS, Lee JM, Kim SK, Kang KW, Zo JI (2005) Intrathoracic gastric emptying of solid food after esophagectomy for esophageal cancer. Ann Thorac Surg 80:443-447. https://doi. org/10.1016/j.athoracsur.2005.02.049

42. Akkerman RD, Haverkamp L, van Hillegersberg R et al (2014) Surgical techniques to prevent delayed gastric emptying after esophagectomy with gastric interposition: a systematic review. Ann Thorac Surg 98:1512-1519. https://doi.org/10.1016/j. athoracsur.2014.06.057

43. Collard JM, Tinton N, Malaise J, Romagnoli R, Otte JB, Kestens PJ (1995) Esophageal replacement: gastric tube or whole stomach? Ann Thorac Surg 60:261-266; discussion 267. https://doi. org/10.1016/0003-4975(95)00411-d

44. Vallbohmer D, Holscher AH, Herbold T et al (2007) Diaphragmatic hernia after conventional or laparoscopicassisted transthoracic esophagectomy. Ann Thorac Surg 84: 1847-1852. https://doi.org/10.1016/j.athoracsur.2007.07.009

45. Konradsson M, Nilsson M (2019) Delayed emptying of the gastric conduit after esophagectomy. J Thorac Dis 11:S835-S844. https:// doi.org/10.21037/jtd.2018.11.80

46. Urschel JD, Blewett CJ, Young JE et al (2002) Pyloric drainage (pyloroplasty) or no drainage in gastric reconstruction after esophagectomy: a meta-analysis of randomized controlled trials. Dig Surg 19:160-164. https://doi.org/10.1159/000064206

47. Arya S, Markar SR, Karthikesalingam A, Hanna GB (2015) The impact of pyloric drainage on clinical outcome following 
esophagectomy: a systematic review. Dis Esophagus 28:326-335. https://doi.org/10.1111/dote.12191

48. Martin JT, Federico JA, McKelvey AA et al (2009) Prevention of delayed gastric emptying after esophagectomy: a single center's experience with botulinum toxin. Ann Thorac Surg 87:17081713; discussion 1713-1704. https://doi.org/10.1016/j.athoracsur. 2009.01.075

49. Tham JC, Nixon M, Ariyarathenam AV, Humphreys L, Berrisford R, Wheatley T, Sanders G (2019) Intraoperative pyloric botulinum toxin injection during Ivor-Lewis gastroesophagectomy to prevent delayed gastric emptying. Dis Esophagus 32. https://doi.org/10. 1093/dote/doy112

50. Yano M, Sugimura K, Miyata H, Motoori M, Tanaka K, Omori T, Ohue M, Sakon M (2020) Randomized comparison of gastric tube reconstruction with and without duodenal diversion plus Roux-enY anastomosis after esophagectomy. Ann Surg 272:48-54. https:// doi.org/10.1097/SLA.0000000000003557

51. Konradsson M, van Berge Henegouwen MI, Bruns C, Chaudry MA, Cheong E, Cuesta MA, Darling GE, Gisbertz SS, Griffin SM, Gutschow CA, van Hillegersberg R, Hofstetter W, Hölscher AH, Kitagawa Y, van Lanschot JJB, Lindblad M, Ferri LE, Low DE, Luyer MDP, Ndegwa N, Mercer S, Moorthy K, Morse CR, Nafteux P, Nieuwehuijzen GAP, Pattyn P, Rosman C, Ruurda JP, Räsänen J, Schneider PM, Schröder W, Sgromo B, van Veer H, Wijnhoven BPL, Nilsson M (2020) Diagnostic criteria and symptom grading for delayed gastric conduit emptying after esophagectomy for cancer: international expert consensus based on a modified Delphi process. Dis Esophagus 33. https://doi.org/10.1093/ dote/doz074

52. Shin AS, Camilleri M (2013) Diagnostic assessment of diabetic gastroparesis. Diabetes 62:2667-2673. https://doi.org/10.2337/ db12-1706

53. Desprez C, Melchior C, Wuestenberghs F, Huet E, Zalar A, Jacques J, Leroi AM, Gourcerol G (2020) Pyloric distensibility measurement after gastric surgery: which surgeries are associated with pylorospasm? Neurogastroenterol Motil 32:e13790. https:// doi.org/10.1111/nmo.13790

54. Jagtap N, Kalapala R, Reddy DN (2020) Assessment of pyloric sphincter physiology using functional luminal imaging probe in healthy volunteers. J Neurogastroenterol Motil 26:391-396. https://doi.org/10.5056/jnm19200

55. Tonini M, Cipollina L, Poluzzi E, Crema F, Corazza GR, de Ponti F (2004) Review article: clinical implications of enteric and central D2 receptor blockade by antidopaminergic gastrointestinal prokinetics. Aliment Pharmacol Ther 19:379-390. https://doi. $\operatorname{org} / 10.1111 / \mathrm{j} .1365-2036.2004 .01867 . x$

56. Pasricha PJ, Pehlivanov N, Sugumar A, Jankovic J (2006) Drug insight: from disturbed motility to disordered movement-a review of the clinical benefits and medicolegal risks of metoclopramide. Nat Clin Pract Gastroenterol Hepatol 3:138-148. https://doi.org/ 10.1038/ncpgasthep0442

57. Stevens JE, Jones KL, Rayner CK, Horowitz M (2013) Pathophysiology and pharmacotherapy of gastroparesis: current and future perspectives. Expert Opin Pharmacother 14:11711186. https://doi.org/10.1517/14656566.2013.795948

58. Collard JM, Romagnoli R, Otte JB, Kestens PJ (1999) Erythromycin enhances early postoperative contractility of the denervated whole stomach as an esophageal substitute. Ann Surg 229:337-343. https://doi.org/10.1097/00000658199903000-00006

59. Gutschow CA, Collard JM, Romagnoli R, Michel JM, Salizzoni M, Hölscher AH (2001) Bile exposure of the denervated stomach as an esophageal substitute. Ann Thorac Surg 71:1786-1791. https://doi.org/10.1016/s0003-4975(01)02535-8

60. Ericson J, Sunde B, Lindblad M, Nilsson M, Lundell L, Tsai JA (2013) Large-diameter (30-35 mm) pneumatic balloon dilatation of the pylorus in patients with gastric outlet obstruction symptoms after esophagectomy. Scand J Surg 102:83-86. https://doi.org/10. $1177 / 1457496913482254$

61. Kim JH, Lee HS, Kim MS, Lee JM, Kim SK, Zo JI (2008) Balloon dilatation of the pylorus for delayed gastric emptying after esophagectomy. Eur J Cardiothorac Surg 33:1105-1111. https://doi.org/10.1016/j.ejcts.2008.03.012

62. Lanuti M, DeDelva P, Morse CR, Wright CD, Wain JC, Gaissert HA, Donahue DM, Mathisen DJ (2011) Management of delayed gastric emptying after esophagectomy with endoscopic balloon dilatation of the pylorus. Ann Thorac Surg 91:1019-1024. https://doi.org/10.1016/j.athoracsur.2010.12.055

63. Maus MK, Leers J, Herbold T et al (2016) Gastric outlet obstruction after esophagectomy: retrospective analysis of the effectiveness and safety of postoperative endoscopic pyloric dilatation. World J Surg 40:2405-2411. https://doi.org/10.1007/s00268016-3575-1

64. Su B, Callahan ZM, Kuchta K, Linn JG, Haggerty SP, Denham W, Ujiki MB (2020) Use of impedance planimetry (Endoflip) in foregut surgery practice: experience of more than 400 cases. J Am Coll Surg 231:160-171. https://doi.org/10.1016/j.jamcollsurg. 2020.02.017

65. Malik Z, Kataria R, Modayil R, Ehrlich AC, Schey R, Parkman HP, Stavropoulos SN (2018) Gastric per oral endoscopic myotomy (G-POEM) for the treatment of refractory gastroparesis: early experience. Dig Dis Sci 63:2405-2412. https://doi.org/10. 1007/s10620-018-4976-9

66. Chung H, Dallemagne B, Perretta S et al (2014) Endoscopic pyloromyotomy for postesophagectomy gastric outlet obstruction. Endoscopy 46(Suppl 1 UCTN):E345-E346. https://doi.org/10. 1055/s-0034-1377599

67. Asti E, Lovece A, Bonavina L (2016) Thoracoscopic implant of neurostimulator for delayed gastric conduit emptying after esophagectomy. J Laparoendosc Adv Surg Tech A 26:299-301. https:// doi.org/10.1089/lap.2016.0089

68. Salameh JR, Aru GM, Bolton W, Abell TL (2008) Electrostimulation for intractable delayed emptying of intrathoracic stomach after esophagectomy. Ann Thorac Surg 85:14171419. https://doi.org/10.1016/j.athoracsur.2007.09.044

69. Ukleja A (2005) Dumping syndrome: pathophysiology and treatment. Nutr Clin Pract 20:517-525. https://doi.org/10.1177/ 0115426505020005517

70. Nakamura M, Hosoya Y, Yano M, Doki Y, Miyashiro I, Kurashina K, Morooka Y, Kishi K, Lefor AT (2011) Extent of gastric resection impacts patient quality of life: the Dysfunction After Upper Gastrointestinal Surgery for Cancer (DAUGS32) scoring system. Ann Surg Oncol 18:314-320. https://doi.org/10. 1245/s10434-010-1290-y

71. Demos NJ, Kulkarni VA, Port A, Micale J (1993) Control of postresection gastroesophageal reflux: the intercostal pedicle esophagogastropexy experience of 26 years. Am Surg 59:137148

72. Snook JA, Wells AD, Prytherch DR, Evans DH, Bloom SR, Colin-Jones DG (1989) Studies on the pathogenesis of the early dumping syndrome induced by intraduodenal instillation of hypertonic glucose. Gut 30:1716-1720. https://doi.org/10.1136/gut. 30.12.1716

73. Burt M, Scott A, Williard WC, Pommier R, Yeh S, Bains MS, Turnbull AD, Fortner JG, McCormack PM, Ginsberg RJ (1996) Erythromycin stimulates gastric emptying after esophagectomy with gastric replacement: a randomized clinical trial. J Thorac Cardiovasc Surg 111:649-654. https://doi.org/10.1016/s00225223(96)70318-5

74. Andreasen JJ, Orskov C, Holst JJ (1994) Secretion of glucagonlike peptide-1 and reactive hypoglycemia after partial gastrectomy. Digestion 55:221-228. https://doi.org/10.1159/000201151 
75. Holst JJ (1994) Glucagonlike peptide 1: a newly discovered gastrointestinal hormone. Gastroenterology 107:1848-1855. https:// doi.org/10.1016/0016-5085(94)90831-1

76. Miholic J, Orskov C, Holst JJ et al (1993) Postprandial release of glucagon-like peptide-1, pancreatic glucagon, and insulin after esophageal resection. Digestion 54:73-78. https://doi.org/10. $1159 / 000201016$

77. Sigstad H (1970) A clinical diagnostic index in the diagnosis of the dumping syndrome. Changes in plasma volume and blood sugar after a test meal. Acta Med Scand 188:479-486

78. van der Kleij FG, Vecht J, Lamers CB et al (1996) Diagnostic value of dumping provocation in patients after gastric surgery. Scand J Gastroenterol 31:1162-1166. https://doi.org/10.3109/ 00365529609036905

79. Scarpellini E, Arts J, Karamanolis G, Laurenius A, Siquini W, Suzuki H, Ukleja A, van Beek A, Vanuytsel T, Bor S, Ceppa E, di Lorenzo C, Emous M, Hammer H, Hellström P, Laville M, Lundell L, Masclee A, Ritz P, Tack J (2020) International consensus on the diagnosis and management of dumping syndrome. Nat Rev Endocrinol 16:448-466. https://doi.org/10.1038/s41574-0200357-5

80. Berg P, McCallum R (2016) Dumping syndrome: a review of the current concepts of pathophysiology, diagnosis, and treatment. Dig Dis Sci 61:11-18. https://doi.org/10.1007/s10620-015-3839$\mathrm{x}$

81. Wang P, Li Y, Sun H, Zhang R, Liu X, Liu S, Wang Z, Zheng Y, Yu Y, Chen X, Li H, Zhang J, Liu Q (2019) Analysis of the associated factors for severe weight loss after minimally invasive McKeown esophagectomy. Thorac Cancer 10:209-218. https:// doi.org/10.1111/1759-7714.12934

82. Weimann A, Braga M, Carli F, Higashiguchi T, Hübner M, Klek S, Laviano A, Ljungqvist O, Lobo DN, Martindale R, Waitzberg DL, Bischoff SC, Singer P (2017) ESPEN guideline: clinical nutrition in surgery. Clin Nutr 36:623-650. https://doi.org/10.1016/j. clnu.2017.02.013

83. Weimann A, Braga M, Harsanyi L, Laviano A, Ljungqvist O, Soeters P, DGEM (German Society for Nutritional Medicine), Jauch KW, Kemen M, Hiesmayr JM, Horbach T, Kuse ER, Vestweber KH, ESPEN (European Society for Parenteral and Enteral Nutrition) (2006) ESPEN guidelines on enteral nutrition: surgery including organ transplantation. Clin Nutr 25:224-244. https://doi.org/10.1016/j.clnu.2006.01.015

84. Braga M, Ljungqvist O, Soeters P, Fearon K, Weimann A, Bozzetti F, ESPEN (2009) ESPEN guidelines on parenteral nutrition: surgery. Clin Nutr 28:378-386. https://doi.org/10.1016/j. clnu.2009.04.002

85. Huddy JR, Macharg FM, Lawn AM et al (2013) Exocrine pancreatic insufficiency following esophagectomy. Dis Esophagus 26: 594-597. https://doi.org/10.1111/dote.12004

86. Veeralakshmanan P, Tham JC, Wright A et al (2020) Nutritional deficiency post esophageal and gastric cancer surgery: A quality improvement study. Ann Med Surg 56:19-22. https://doi.org/10. 1016/j.amsu.2020.05.032

87. Gutschow CA, Schröder W, Hölscher AH (1998) Funktion des Ersatzorgans nach Ösophagektomie. Chir Gastroenterol 14:300 306

88. Aaronson NK, Ahmedzai S, Bergman B, Bullinger M, Cull A, Duez NJ, Filiberti A, Flechtner H, Fleishman SB, , Haes CJM, Kaasa S, Klee M, Osoba D, Razavi D, Rofe PB, Schraub S, Sneeuw K, Sullivan M, Takeda F The European Organization for Research and Treatment of Cancer QLQ-C30: a quality-oflife instrument for use in international clinical trials in oncology. J Natl Cancer Inst 1993; 85: 365-376. doi:https://doi.org/10.1093/ jnci/85.5.365

89. Eypasch E, Williams JI, Wood-Dauphinee S, Ure BM, Schmulling C, Neugebauer E, Troidl H (1995) Gastrointestinal
Quality of Life Index: development, validation and application of a new instrument. Br J Surg 82:216-222. https://doi.org/10.1002/ bjs. 1800820229

90. Zieren HU, Jacobi CA, Zieren J, Müller JM (1996) Quality of life following resection of oesophageal carcinoma. Br J Surg 83: 1772-1775. https://doi.org/10.1002/bjs.1800831235

91. Derogar M, Lagergren P (2012) Health-related quality of life among 5-year survivors of esophageal cancer surgery: a prospective population-based study. J Clin Oncol 30:413-418. https://doi. org/10.1200/JCO.2011.38.9791

92. Schandl A, Lagergren J, Johar A, Lagergren P (2016) Healthrelated quality of life 10 years after oesophageal cancer surgery. Eur J Cancer 69:43-50. https://doi.org/10.1016/j.ejca.2016.09. 032

93. Greene CL, DeMeester SR, Augustin F et al (2014) Long-term quality of life and alimentary satisfaction after esophagectomy with colon interposition. Ann Thorac Surg 98:1713-1719; discussion 1719-1720. https://doi.org/10.1016/j.athoracsur.2014.06.088

94. Noordman BJ, Verdam MGE, Lagarde SM, Hulshof MCCM, van Hagen P, van Berge Henegouwen MI, Wijnhoven BPL, van Laarhoven HWM, Nieuwenhuijzen GAP, Hospers GAP, Bonenkamp JJ, Cuesta MA, Blaisse RJB, Busch OR, ten Kate FJW, Creemers GJM, Punt CJA, Plukker JTM, Verheul HMW, Spillenaar Bilgen EJ, van Dekken H, van der Sangen MJC, Rozema T, Biermann K, Beukema JC, Piet AHM, van Rij CM, Reinders JG, Tilanus HW, Steyerberg EW, van der Gaast A, Sprangers MAG, van Lanschot JJB (2018) Effect of neoadjuvant chemoradiotherapy on health-related quality of life in esophageal or junctional cancer: results from the randomized CROSS trial. J Clin Oncol 36:268-275. https://doi.org/10.1200/JCO.2017.73. 7718

95. Hayashi M, Kawakubo H, Shoji Y, Mayanagi S, Nakamura R, Suda K, Wada N, Takeuchi H, Kitagawa Y (2019) Analysis of the effect of early versus conventional nasogastric tube removal on postoperative complications after transthoracic esophagectomy: a single-center, randomized controlled trial. World J Surg 43:580 589. https://doi.org/10.1007/s00268-018-4825-1

96. De Boer AG, Genovesi PI, Sprangers MA et al (2000) Quality of life in long-term survivors after curative transhiatal oesophagectomy for oesophageal carcinoma. Br J Surg 87: 1716-1721. https://doi.org/10.1046/j.1365-2168.2000.01600.x

97. Deschamps C, Nichols FC 3rd, Cassivi SD et al (2005) Long-term function and quality of life after esophageal resection for cancer and Barrett's. Surg Clin North Am 85:649-656, xi. https://doi.org/ 10.1016/j.suc.2005.01.018

98. Mantoan S, Cavallin F, Pinto E, Saadeh LM, Alfieri R, Cagol M, Bellissimo MC, Castoro C, Scarpa M (2018) Long-term quality of life after esophagectomy with gastric pull-up. J Surg Oncol 117: 970-976. https://doi.org/10.1002/jso.24995

99. Moraca RJ, Low DE (2006) Outcomes and health-related quality of life after esophagectomy for high-grade dysplasia and intramucosal cancer. Arch Surg 141:545-549; discussion 549551. https://doi.org/10.1001/archsurg.141.6.545

100. Djarv T, Lagergren J, Blazeby JM et al (2008) Long-term healthrelated quality of life following surgery for oesophageal cancer. $\mathrm{Br}$ J Surg 95:1121-1126. https://doi.org/10.1002/bjs.6293

101. Donohoe CL, McGillycuddy E, Reynolds JV (2011) Long-term health-related quality of life for disease-free esophageal cancer patients. World J Surg 35:1853-1860. https://doi.org/10.1007/ s00268-011-1123-6

102. Gockel I, Gonner U, Domeyer M et al (2010) Long-term survivors of esophageal cancer: disease-specific quality of life, general health and complications. J Surg Oncol 102:516-522. https://doi. org/10.1002/jso.21434

103. Jacobs M, Macefield RC, Elbers RG, Sitnikova K, Korfage IJ, Smets EMA, Henselmans I, van Berge Henegouwen MI, de 
Haes JCJM, Blazeby JM, Sprangers MAG (2014) Meta-analysis shows clinically relevant and long-lasting deterioration in healthrelated quality of life after esophageal cancer surgery. Qual Life Res 23:1155-1176. https://doi.org/10.1007/s11136-013-0576-5

104. Soriano TT, Eslick GD, Vanniasinkam T (2018) Long-term nutritional outcome and health related quality of life of patients following esophageal cancer surgery: a meta-analysis. Nutr Cancer 70: 192-203. https://doi.org/10.1080/01635581.2018.1412471

105. Zhang Y, Yang X, Geng D, Duan Y, Fu J (2018) The change of health-related quality of life after minimally invasive esophagectomy for esophageal cancer: a meta-analysis. World J Surg Oncol 16:97. https://doi.org/10.1186/s12957-018-1330-9

106. Blazeby JM, Sanford E, Falk SJ, Alderson D, Donovan JL (2005) Health-related quality of life during neoadjuvant treatment and surgery for localized esophageal carcinoma. Cancer 103:17911799. https://doi.org/10.1002/cncr.20980

107. Reynolds JV, McLaughlin R, Moore J, Rowley S, Ravi N, Byrne PJ (2006) Prospective evaluation of quality of life in patients with localized oesophageal cancer treated by multimodality therapy or surgery alone. Br J Surg 93:1084-1090. https://doi.org/10.1002/ bjs. 5373

108. Schmidt HM, Gisbertz SS, Moons J, Rouvelas I, Kauppi J, Brown A, Asti E, Luyer M, Lagarde SM, Berlth F, Philippron A, Bruns C, Hölscher A, Schneider PM, Raptis DA, Henegouwen MIB, Nafteux P, Nilsson M, Räsanen J, Palazzo F, Rosato E, Mercer
S, Bonavina L, Nieuwenhuijzen G, Wijnhoven BPL, Schröder W, Pattyn P, Grimminger PP, Gutschow CA (2017) Defining benchmarks for transthoracic esophagectomy: a multicenter analysis of total minimally invasive esophagectomy in low risk patients. Ann Surg 266:814-821. https://doi.org/10.1097/SLA. 0000000000002445

109. Fransen LFC, Berkelmans GHK, Asti E, van Berge Henegouwen MI, Berlth F, Bonavina L, Brown A, Bruns C, van Daele E, Gisbertz SS, Grimminger PP, Gutschow CA, Hannink G, Hölscher AH, Kauppi J, Lagarde SM, Mercer S, Moons J, Nafteux P, Nilsson M, Palazzo F, Pattyn P, Raptis DA, Räsanen J, Rosato EL, Rouvelas I, Schmidt HM, Schneider PM, Schröder W, van der Sluis PC, Wijnhoven BPL, Nieuwenhuijzen GAP, Luyer MDP (2020) The effect of postoperative complications after minimally invasive esophagectomy on long-term survival: an international multicenter cohort study. Ann Surg. https://doi.org/10. 1097/SLA.0000000000003772

110. Akiyama H, Hiyama M, Hashimoto C (1976) Resection and reconstruction for carcinoma of the thoracic oesophagus. Br J Surg 63:206-209. https://doi.org/10.1002/bjs. 1800630310

Publisher's note Springer Nature remains neutral with regard to jurisdictional claims in published maps and institutional affiliations. 